\title{
Community Awareness on Earthquake and Assessment on Earthquake Risk Reduction Practices in a Philippine Municipality
}

\author{
Jerose M. Dacanay ${ }^{1}$, Ma. Gladys B. Mauro ${ }^{1}$, Jimmuel A. Sandoval ${ }^{1} \&$ Genalyn P. Lualhati $^{1}$ \\ 1 College of Teacher Education, Batangas State University JPLPC-Malvar Campus, Batangas Province, \\ Philippines \\ Correspondence: Genalyn P. Lualhati, College of Teacher Education, Batangas State University JPLPC-Malvar \\ Campus, Batangas Province, Philippines.
}

Received: November 6, 2018; Accepted: December 5, 2018; Published: December 17, 2018

\begin{abstract}
This study determined the level of awareness on earthquake and assessment on earthquake risk reduction practices in a Philippine municipality which covered 150 household heads from 15 barangays of Malvar. The study used the descriptive method of research and used self-made questionnaire to gather the necessary data. For analysis, weighted mean and Pearson $r$ were used. In the light of the significant findings revealed in the study, the following conclusions were drawn: the respondents were aware of the occurrence earthquake and the earthquake risk reduction practices of the Municipality were good. It was found out that there is no significant relationship existed between the respondents' level of awareness and their assessed risk reduction practices. The findings of the study afforded the researchers in drawing various suggested activities to strengthen the implementation of earthquake risk reduction practices in the Philippines. Based on the conclusions formulated in the study, the following recommendations were offered. The officials of the municipality may provide funds in order to supply the basic needs and facilities of the community. The officials of the municipality may improve their way of warning the public especially by providing visible signages that would be a great help for them to become aware of the different hazards present to the locality. The officials of municipality may provide map of evacuation in every barangay that could help the community to easily find their route after such dilemma. The officials of Malvar may improve the trainings and activities that would help the Search and Rescue teams to respond quickly when a phenomenon happens. This will decrease the possibility of an injured person in critical condition.
\end{abstract}

Keywords: community awareness, earthquake, risk reduction practices

\section{Introduction}

Nature gives human a lot of good things, it serves as home that keeps every individual from danger; and it also serves as the source of food that everyone needs for daily lives in order to live. In short, the reason why people are here in this world is to protect and conserve the source of life. However, because of every individual unlimited wants, humans start to abuse the blessings the nature gives.

Over the centuries, humans discovered different practices that enable them to become more innovative on their way of living. Humans tend to diminish plant trees in order to build buildings and houses, make factories that emit black smoke that goes beyond the atmosphere, destruct mountains in order to get gold and other minerals. Humans become possessed in order to sustain their needs without realizing their malpractices towards the nature can cause climate change.

Climate change is the result of people's unlimited wants, and due to climate change, natural disaster is getting worst. Earthquake is one of the natural disasters that cause death. In the Philippines, strong earthquakes happen because it is one of the countries that lay on the Pacific Ring of Fire. One of these horrific phenomena happened on October 2013. With the magnitude of 7.2, hundreds of people died and almost thousands were injured. This phenomenon left Philippine history a horrible memory that of how the nature gives and takes a lot.

Another devastating earthquake that struck in the Philippines was the Mindoro earthquake on 1994 jointed by tsunami, and Luzon earthquake on 1990. The said earthquakes brought nightmare to the people. The earthquake and tsunami in Mindoro affected 22,452 families in 13 out of 15 municipalities - a total of 273 barangays - in Oriental Mindoro, with 78 confirmed dead and 430 more injured. The combined effects of the earthquake and the tsunami totally destroyed 1,530 houses and partially damaged 6,036 more. 
The Luzon earthquake had an estimated 1,621 people killed, most of the fatalities was located in Central Luzon and the Cordillera region. The earthquake caused damage within an area of about 20,000 square kilometers, stretching from the mountains of the Cordillera Administrative Region and through the Central Luzon region. The earthquake caused collapsed buildings, including hotels, factories, government and university buildings, as well as many private homes and establishments in Baguio, Cabanatuan City, Nueva Ecija, Dagupan City, Pangasinan, and La Union (Orallo, 2011).

On April 4, 2017, the province of Batangas was hit by a tectonic earthquake with a 5.5 magnitude locating the epicenter 5 kilometers south of Tingloy, Batangas. Metro Manila and nearby provinces felt shaking at Intensity 3 while the province of Bulacan felt Intensity 4, as well as the Batangas City. On April 7 at 1:00 PM, the Philippine Institute of Volcanology and Seismology (PHIVOLCS) stated that they have recorded 934 aftershocks; 118 of which were plotted while 14 were reportedly felt. The Pacific Tsunami Warning Center announced that no tsunami warning followed the earthquake.

Additionally, two earthquakes occurred near the towns of Mabini and Tanauan on April 8. PHIVOLCS recorded the first earthquake which occurred near Mabini at 3:07 pm having a moment magnitude of 5.6 while the second earthquake which happened in Talaga, Tanauan at 3:09 pm was recorded as having a moment magnitude of 6.0. The United States Geological Survey (USGS) recorded the first 5.7 magnitude earthquake while the second magnitude 5.9 earthquake.

Earthquakes happen with no warning; therefore, life-protecting actions must be taken at the first indication of ground shaking. According to Mitra (2010), everyone has the means to adopt no regret measures. Earthquakes in themselves do not kill people. Poor planning, inadequate preparedness and the lack of application of building standards do. It is being said that people should and must know how to act and how to become prepared when an earthquake strikes whenever they are at school, office, or even in their homes.

Republic Act No. 10121, "Philippine Disaster Risk Reduction and Management Act of 2010" Section 12- Local Disaster Risk Reduction and Management Office (LDRRMO) states that every province, city, municipality and Barangay Disaster Risk Reduction and Management Committee (BDRRMC) in every barangay shall be responsible for setting the direction, development, implementation, and coordination of disaster risk management programs within their territorial jurisdiction.

In accordance with that, the cities of Calamba, Laguna, Batangas, Rizal, and Quezon (CALABARZON) held the 2nd Quarter Nationwide Simultaneous Earthquake Drill last June 22, 2016 were sirens, alarms, and vehicle horns were sounded off to signal the start of the \#PAGYANIG 2016 2nd Quarter Nationwide Simultaneous Earthquake Drill. All government units from the provincial levels, all government and private offices, all private and public learning institutions, and all families and individuals were highly encouraged to do the Duck, Cover, and Hold upon hearing the signal, and evacuate outside their offices/ homes to their respective identified/designated evacuation areas.

Disaster preparedness was defined by law as the knowledge and capacities developed by governments, professional response and recovery organizations, communities and individuals to effectively anticipate, respond to, and recover from, the impacts of likely, imminent or current hazards events or condition. Further, activities revolving around community awareness and understanding, contingency planning, and conduct of local drills were also considered. (Natural Disaster Risk Reduction and Management Plan, 2011)

Earthquake awareness and preparedness is not accomplished overnight. It takes place in a series of small steps taken at home, at work, at school, in community and the region. It is accomplished through actions by individuals, families, organizations/institutions, and government. Though in case of earthquake, the hazard cannot be stopped, the impact can be significantly reduced by effective preparedness and mitigation measures in advance, which has been experienced during recent earthquake of September 2011 in Nepal. A field survey conducted immediately after earthquake shown that more than 80 percent saved their lives following the safe behavior during shaking (Jimee et al., 2012).

Therefore, awareness raising programs should be focused on the local communities; and should spell out its specific role taking into consideration the community's needs and their level of understanding. The awareness among the general people will create the demand of safety, which ultimately pushes the government for solid plans of actions. In this regard, the need of sensitization for policy/decision makers is also equally important so that the government will give high priority to public awareness; and the formulation of the policies/regulations and action plans to be followed and implemented in the real world (Jimee et al., 2012). 
Having this kind of activity is important to study not just only for the community, but also for everyone's safety because the researchers believed that it is important to have not just the understanding about the proper and improper practices when experiencing such disaster. It is not the understanding that is important but how this understanding is good enough to protect people from danger. It is important to know the possible things that could happen while the earthquake is happening, where to go after the earthquake, the procedure if there is casualty, and how to help others. Natural disaster is impossible to suppress and it happens in time that people did not expect so it is important to become equipped with not just only the knowledge but also with the preparedness that helps to improve individual safety (Natural Disaster Risk Reduction and Management Plan, 2011). In this regard, the researchers conducted a study on the community awareness on earthquake and assessment on earthquake risk reduction practices in the Philippines, with an end view of suggesting activities to the Local Government Unit that will strengthen the program.

\section{Objectives of the Study}

This descriptive study concentrated on the awareness of the community on earthquake and assessment on earthquake risk reduction practices in the Philippine municipality among the household heads of Malvar, with an end view of drawing the suggested activities to the office of the disaster information and risk reduction program of the Municipality of Malvar. The study sought to determine the level of awareness on earthquake as a natural disaster. This undertaking revealed the respondents' assessment on risk reduction practices in response to earthquake in terms of early warning, evacuation plan and structure, and search and rescue.

With the importance of creating civic-minded and environmentally literate populace that had been previously discussed that this study was conceptualized. The researchers, who are future science secondary teachers believe that this study will acquaint the people and the community to the importance of being ready and having knowledge when it comes to unexpected natural phenomenon, specifically, the earthquake.

\section{Materials and Methods}

\subsection{Research Design}

The researchers utilized descriptive research methodology. Natural disaster is one of the existing disastrous conditions in the country. The common natural hazard that is being experienced by the country is typhoon. The researchers believed that it would be best to describe the present situation through utilizing the descriptive research design.

\subsection{Subject of the Study}

It was administered in the 15 barangays in the Local Government Unit of Malvar. Considering the study's scope and time allotted to conduct the study, the researchers only used 10 household heads per barangay. Household heads are in best position to answer the instrument as they are the decision-maker in their respective homes. Hence, the total population of the respondents was 150 .

\subsection{Instrumentation}

The study used a researcher-made questionnaire to determine the community awareness on earthquake and the assessment on earthquake risk reduction practices in the Philippines. The questionnaire was composed of two parts. The first part focused on the respondents' level of awareness on earthquake as a natural disaster. The next part deals with the respondents' assessments on earthquake risk reduction practices in terms of early warning system, evacuation plan and structures, and search and rescue.

In determining the respondents' level of awareness on earthquake, the following mean ranges with their corresponding interpretation was used.

\begin{tabular}{ccc}
\hline Scale & Mean Ranges & Interpretation \\
\hline 4 & $3.51-4.00$ & Strongly Agree/Highly Aware \\
3 & $2.51-3.50$ & Agree/Aware \\
2 & $1.51-2.50$ & Slightly Agree/Slightly Aware \\
1 & $1.00-1.50$ & Disagree/Not Aware \\
\hline
\end{tabular}

In determining the respondents' assessment on earthquake risk reduction practices, the following mean ranges with their corresponding interpretation was used. 


\begin{tabular}{lll}
\hline Numerical Value & Mean Ranges & Interpretation \\
\hline 4 & $3.51-4.00$ & Strongly Agree/Highly Practiced \\
3 & $2.51-3.50$ & Agree/Practiced \\
2 & $1.51-2.50$ & Slightly Agree/Slightly Practiced \\
1 & $1.00-1.50$ & Disagree/Not Practiced \\
\hline
\end{tabular}

The data gathered were subjected to statistical treatment using mean and Pearson $\mathrm{r}$.

\subsection{Data Collection Procedure}

After finalizing the title and the statement of the problem, the construction of the questionnaire started. The researchers looked for information and organized the proposal. They made a letter for the approval of Associate Dean of College of Teacher Education and Dean of Colleges to conduct their study in the Local Government Unit of Malvar. The researchers coordinated with the barangay captains and presented the letter for distributing and administering the questionnaire among the household heads in the Local Government Unit of Malvar. They explained to them the nature, goals and objectives of the study. The retrieved questionnaires were tallied, tabulated and interpreted in accordance to the items.

\section{Results and Discussions}

The data obtained underwent a thorough analysis and interpretation. This analysis includes a reiteration of the purpose of the study and the results of the data collected on the sample of household heads in the Local Government Unit of Malvar who responded to the survey.

Table 1. Respondents' level of awareness on earthquake

\begin{tabular}{|c|c|c|}
\hline Item Statements & Mean & Verbal Interpretation \\
\hline $\begin{array}{l}\text { 1. An earthquake is caused by the pressure generated by the magma } \\
\text { from faults toward the earth's surface. }\end{array}$ & 3.38 & Agree \\
\hline $\begin{array}{l}\text { 2. An earthquake is classified according to the shake strength and } \\
\text { duration of their seismic waves. }\end{array}$ & 3.29 & Agree \\
\hline $\begin{array}{l}\text { 3. The Philippine Institute of Volcanology and Seismology } \\
\text { (PHIVOLCS) is the government agency which provides information on } \\
\text { the activities of volcanoes, earthquakes and tsunamis. }\end{array}$ & 3.67 & Strongly agree \\
\hline $\begin{array}{l}\text { 4. The PHIVOLCS provides a classification system for the volcanoes } \\
\text { of the country. }\end{array}$ & 3.52 & Strongly agree \\
\hline 5. The Philippines has a lot of trenches and faults. & 3.11 & Agree \\
\hline $\begin{array}{l}\text { 6. An earthquake is considered as a dangerous and hazardous natural } \\
\text { disaster that may cause loss of life, injury, or other health impacts, } \\
\text { property damage and loss of livelihoods. }\end{array}$ & 3.69 & Strongly agree \\
\hline $\begin{array}{l}\text { 7. An earthquake can cause fire through damaged electrical power and } \\
\text { gas lines. }\end{array}$ & 3.35 & Agree \\
\hline $\begin{array}{l}\text { 8. An earthquake is considered as a tectonic activity because the } \\
\text { earth's surface is active. }\end{array}$ & 3.16 & Agree \\
\hline $\begin{array}{l}\text { 9. There are } 3 \text { kinds of seismic waves an earthquake can produce such } \\
\text { as primary, secondary, and surface waves. }\end{array}$ & 3.14 & Agree \\
\hline $\begin{array}{l}\text { 10. Earthquake occurs because of sudden release of stress built up along } \\
\text { fault lines. }\end{array}$ & 3.20 & Agree \\
\hline Composite Mean & 3.35 & Aware \\
\hline
\end{tabular}

In determining the respondents' level of awareness on earthquake, the result indicates that household heads were aware regarding this matter as shown at Table 1. This is justified by the study of Jimee et. al. (2012) showed the orientation program that the National Society for Earthquake Technology (NSET) had been conducted which focused in massive scale focusing different level of stakeholders and individuals in the country. Mainly the orientation programs focused on: earthquake basics and existing risks in earthquake preparedness and risk reduction measures; ways to respond during and after earthquake; pre-positioning emergency supplies; acquiring 
lifesaving skills; and safer construction, etc. The earthquake awareness massage is conveyed to more than 21,000 families.

Table 2. Respondents' Assessment on Risk Reduction Practices in Response to Earthquake in terms of Early Warning Systems

\begin{tabular}{l|l|l}
\hline Item Statements & Mean & Verbal Interpretation \\
\hline $\begin{array}{l}\text { 1. Sirens and bells are used to warn the community that there is an } \\
\text { earthquake. }\end{array}$ & 3.18 & Agree \\
2. Barangay mobile patrols roam around to check all areas and provide & 3.25 & Agree \\
assistance. & & Agree \\
3. Orientation program for early warning system is conducted and & 3.28 & \\
educate the community. & & Agree \\
4. The Local Government Unit uses radio and television messages to & 3.23 & \\
warn the public. & 3.16 & Agree \\
5. Visible signages are available to warn the public. & $\mathbf{3 . 2 2}$ & Practice \\
\hline Composite Mean &
\end{tabular}

Table 2 shows that risk reduction practices of the municipality in terms of early warning systems were practice. Orallo (2011), on the development of a quick and accurate communications system is essential for the effective use of early warning information. One of that is the simultaneous wireless communications system using the outdoor loudspeakers and indoor radio receivers to disseminate the disaster information to residents. Tsunami and severe weather warnings are widely provided to citizens via TV radio broadcasts.

Table 3. Respondents' Assessment on Risk Reduction Practices in Response to Earthquake in terms of Evacuation Plans and Structures

\begin{tabular}{l|l|l}
\hline Item Statements & Mean & Verbal Interpretation \\
\hline $\begin{array}{l}\text { 1. Evacuation centers are well prepared and distributed properly for } \\
\text { each barangay. }\end{array}$ & 3.35 & Agree \\
$\begin{array}{l}\text { 2. Each barangay has designated route where to go after an } \\
\text { earthquake. }\end{array}$ & 3.15 & Agree \\
3. The Local Government Unit uses the barangay hall and covered & 3.45 & Agree \\
courts as an alternative evacuation center. \\
$\begin{array}{l}\text { 4. Evacuation map is provided to guide and provide escape in case } \\
\text { of emergency } \\
\text { 5. Development of land plans are used to determine the most } \\
\text { important local danger zone. }\end{array}$ & 3.08 & Agree \\
\hline Composite Mean & $\mathbf{3 . 1 8}$ & Practiced \\
\hline
\end{tabular}

The table above shows that the risk reduction practices in terms of evacuation plans and structures were good with a composite mean of 3.18. This is supported by the study of Becker et.al (2012), creating an evacuation plan is important because many people simply do not know what to do when they are confronted with a dire emergency. When people become overwhelmed by an emergency, it is often difficult for them to think clearly and establish a logical plan from scratch. Having a plan in advance gives even a person in shock a framework to rely on and a path to follow.

Table 3. Respondents' Assessment on Risk Reduction Practices in Response to Earthquake in terms of Search and Rescue

\begin{tabular}{l|l|l}
\hline Item Statements & Mean & Verbal Interpretation \\
\hline $\begin{array}{l}\text { 1. There are trained and licensed medical personnel to treat illnesses/ } \\
\text { injuries. }\end{array}$ & 3.37 & Agree \\
$\begin{array}{l}\text { 2. There are assigned trained and licensed personnel to search and } \\
\text { rescue the victims. }\end{array}$ & 3.34 & Agree
\end{tabular}


3. The Local Government Unit of Malvar has emergency hotlines to easily call for rescue purposes.

4. The search and rescue team responds quickly/ on time to help the victims.

5. There are available facilities for search and rescue such as first aid kit, wheel chairs, stretchers, medicines, etc.

Composite Mean

\begin{tabular}{l|l}
3.13 & Agree \\
3.09 & Agree \\
3.33 & Agree \\
$\mathbf{3 . 2 5}$ & Practiced \\
\hline
\end{tabular}

The respondents' risk reduction practices in response to earthquake in terms of search and rescue possessed a composite mean of 3.25 which denotes a very good result. This can be an indication that the earthquake reduction practices of the municipality in terms of Search and Rescue is considered and prioritized. This will be a great help for the community when the said phenomena happen. Polde (2012) stated that carrying out rescue operation after an earthquake is a complicated and demanding task. Because rescue must be accomplished quickly, all countries in which destructive earthquakes are likely to occur must have advance preparation for rescue operations.

\section{Conclusions and Recommendations}

It was also concluded that the respondents are aware on earthquake as a natural disaster, earthquake risk reduction practices in terms of early warning system, evacuation plan and structure, and search and rescue was practiced by the respondents. There is no significant relationship existed between the respondents' level of awareness and their assessed risk reduction practices.

The findings of the study afforded the researchers in drawing various suggested activities to the office of the disaster information and risk reduction practices of the Local Government Unit of Malvar. The municipality may conduct seminars, workshops and orientation programs on terminologies regarding typhoon and other environmental issues. Drills and simulations in the school and community may be exercised. In addition, they may also raise funds to provide the needed supplies of the community. The aforementioned activities may be considered by the concerned authorities or agencies for maximum implementation and actualization.

\section{References}

Basic Planet Natural Disasters. (2013). Retrieved from http://www.basicplanet.com/natural-disasters/

Buctot, B., et al. (2012). Level of Awareness on Ecological Problems of Second Year Students at Lumbang National High School, Unpublished Thesis, Batangas State University Malvar Campus Malvar, Batangas.

Burkett, E. R., Given, D. D., \& Jones, L. M. (2017). An Earthquake Early Warning System for the United States West Coast. U.S. Geological Survey, 1, 1-4. https://doi.org/10.3133/20143083

Del Mundo, John, P. M., et al. (2014). Implementation of Disaster Preparedness Programs in Coastal Towns along Taal Lake of Batangas, Unpublished Thesis, Batangas States University Malvar Campus, Malvar Batangas.

Erdik, M., Sesetyan, K., Demircioglu, M., Hancilar, U., Zulfikar, C., Cakti, E., ... Harmandar, E. (2010). Rapid Earthquake Hazard and Loss Assessment for Euro-Mediterranean Region. Acta Geophysica, 58(5), 855-892. https://doi.org/10.2478/s11600-010-0027-4

Gerdan, S. (2014). Determination of Disaster Awareness, Attitude Levels and Individual Priorities at Kocaeli University. Eurasian Journal of Educational Research, 55, 159-176. https://doi.org/10.14689/ejer.2014.55.10

Great Shakeout Earthquake Drill. (2013). Retrieved from http://www.extinctiontheory.com/great-shakeoutearthquake-drill-october-17-2013/

Guevarra, J. P., Ancheta, C. A., De La Pena, J. O., Ortega, A. R., \& Lariosa, T. R. (2007). Assessment of Disaster Preparedness in Schools in Luzon Philippines, 2, 78-84.

ICIMOD (International Centre for Integrated Mountain Development). (2009). Public awareness to help manage natural disaster risk. Retrieved from http://www.icimod.org/?q=5273

Jimee, G. K., Upadhyay, B., \& Shrestha S. N. (2012). Earthquake Awareness program as a key for Earthquake Preparedness and Risk Reduction Lessons from Nepal. Awareness for Individuals and Institutions, 1, 1-9.

Laude, J., \& Brago, P. L. (2014). The Philippine Star Nationwide Earthquake. Retrieved from http://beta.philstar.com/headlines/2014/06/29/ 1340220/nationwide-quake-drill-set-july-2

Luzerne, M. (2014). Disaster Risk Reduction and Management in the Philippines. Relevant Current and Future National Hazards, 1, 5-9. 
Mahilum, V., et al. (2008). Mitigating measures and Level of preparedness against risks and disaster among local government units, Unpublished Thesis, Lipa City College, Lipa City Batangas

National Disaster Risk Reduction and Management Plan (NDRRMP) 2011-2028. (2011). Retrieved from http://www.NDRRM_Plan_2011-2028

Natural Disaster. (2017). Retrieved from https://en.wikipedia.org/wiki/Natural_disaster

Orallo, A. D. (2011). Study on Earthquake Risk and Vulnerability Management and Lessons learned. ARDC Visiting Researcher, 1, 7-15.

Paño, J. D., Abao, E. D., \& Boholano, H. B. (2015). Higher Education Institutions' Risk Reduction Implementation: Victor or Victim? Management and Administrative Sciences Review, 4, 647-678.

Piper, C. (2011). A Diagrammatic Framework for Disaster Risk Management. The Disaster Risk Management Cycle, 5, 1-6.

Roque, et al. (2010). Emergency Management Capacity of selected Barangays in the City of Manila, Unpublished Thesis, Philippine College of Criminology

Sobremisana, V. S., \& Pilar, N. N. (2014). Disaster Risk Reduction Mangement in the City of Mandaluyong. Focus on Earthquake Impact Reduction, 5, 1-2.

Strauss, J. A. (2016). Benefits and Costs of Earthquake Early Warning. Seismological Research Letters, 87(3), 765-770. https://doi.org/10.1785/0220150149

UNISDR. (United Nation Office for Disaster Risk Reduction) (2012). Disaster Risk Reduction. Retrieved from https://www.unisdr.org/who-we-are/what-is-drr

USGS. (United States Geological Survey) (2012). Science for a changing world Earthquake Early Warning. Retrieved from https://earthquake.usgs.gov/research/earlywarning/

USGS. (United States Geological Survey) (2012). Science for a changing world The Science of Earthquakes. Retrieved from http://earthquake.usgs.gov/learn/kids/eqscience.php

\section{Copyrights}

Copyright for this article is retained by the author(s), with first publication rights granted to the journal.

This is an open-access article distributed under the terms and conditions of the Creative Commons Attribution license (http://creativecommons.org/licenses/by/4.0/). 